
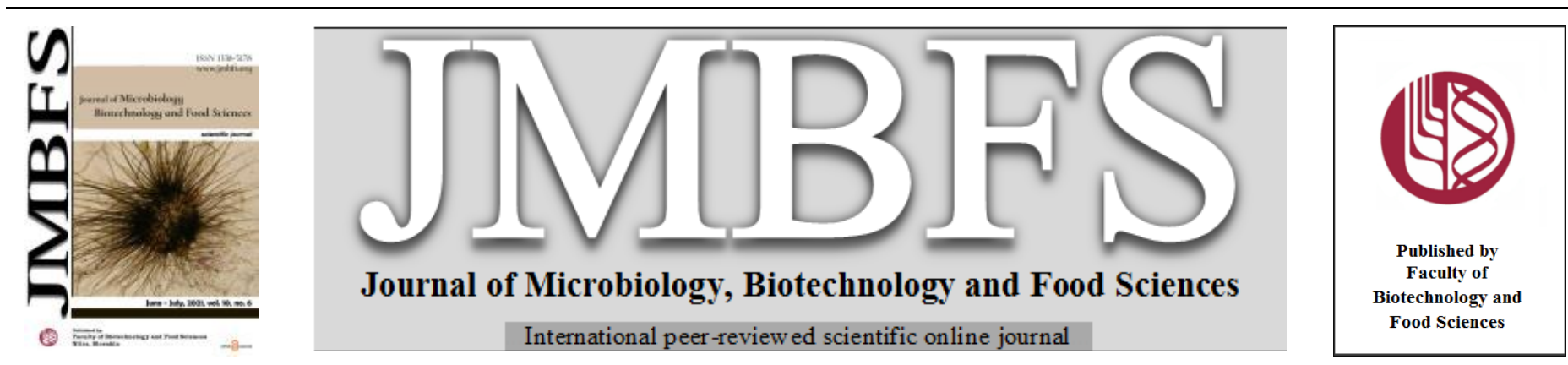

\title{
TOPINAMBUR (THE JERUSALEM ARTICHOKE): NUTRITIONAL VALUE AND ITS APPLICATION IN FOOD PRODUCTS: AN UPDATED TREATISE
}

\section{Mohammad Ali Shariati ${ }^{1, *}$, Muhammad Usman Khan ${ }^{2}$, Lukas Hleba $^{3}$, Carolina Krebs de Souza ${ }^{4}$, Zhaiyk Tokhtarov ${ }^{5}$, Sergei Terentev ${ }^{6}$, Sergey Konovalov ${ }^{7}$, Fluza Arduvanova $^{8}$, Natalya Batishcheva $^{l}$, Ilyas Shigapov $^{I}$, Strigulina Ekaterina ${ }^{I}$, Milyausha Kantimerova $^{I}$}

\author{
Address(es): \\ ${ }^{2}$ Department of Energy Systems Engineering University of Agriculture, Faisalabad, Pakistan. \\ 94976 Nitra, Slovak republic. \\ ${ }^{5}$ Shakarim University of Semey, Semey city, Kazakhstan. \\ ${ }^{6}$ Smolensk State Agricultural Academy, Smolensk, Russian Federation. \\ ${ }^{7}$ Omsk State Agrarian University named after P.A. Stolypin, Omsk, Russian Federation. \\ ${ }^{8}$ Bashkir State Agrarian University, Ufa, Russian Federation.
}

${ }^{1}$ K.G. Razumovsky Moscow State University of technologies and management (The First Cossack University), Moscow, Russian Federation.

${ }^{3}$ Department of Microbiology, Faculty of Biotechnology and Food Sciences, Tr. A. Hlinku 2, Slovak University of Agriculture in Nitra,

${ }^{4}$ Chemical Engineering Graduate Program (PPGEQ), Chemical Engineering Department, Regional University of Blumenau (FURB), Blumenau 89030-000, Brazil.

*Corresponding author: shariatymohammadali@gmail.com

https://doi.org/10.15414/jmbfs.4737

\section{ARTICLE INFO}

Received 10. 12. 2020

Revised 21. 4. 2021

Accepted 29. 4. 2021

Published 1. 6. 2021

$\underline{\text { Regular article }}$

open $\odot$ access

\section{ABSTRACT}

This article presents a review of the scientific literature on the nutritional value of topinambur (Jerusalem artichoke) and its potential use in the formulation of food products. The scientific review covers the chemical, amino-acid, vitamin, mineral composition of topinambur, its pharmacological and therapeutic and prophylactic effect on the human organism. The distinctive features of topinambur are the content of more than $20 \%$ of dry substances, among which up to $80 \%$ contains a polymeric homologue of fructose - inulin. The content of pectin substances varies up to $11 \%$ of dry weight. Consumption of topinambur as a part of foodstuffs has a beneficial effect on absolutely all the chains and causes of diseases of the digestive system, cardiovascular system and liver. A number of findings about the use of topinambur roots in the process of preparation of meat, milk, confectionary and bread products are presented, its positive effect on the nutritional value and consumer properties of the final product is characterized. Utilization of Jerusalem artichoke in formulation of various food products is a good way to increase the alternative usage area of them.

Keywords: topinambur, roots, inulin, formulation, topinambur powder, food products

\section{INTRODUCTION}

In the world agriculture the area of topinambur (The Jerusalem artichoke) cultivation is 2.5 million hectares, in the USA - 700 thousand hectares, in France - 500 thousand hectares, in Austria - 130 thousand hectares, with an average yield of 50-60 tons of tubers per hectare. The major directions of topinambur processing are production of inulin, fructose syrups, sweeteners, alcohol, fodder yeast, topinambur concentrates in the form of tablets, capsules and powder for diabetes mellitus patients, as well as other products of high nutritional value for use in food industry, medicine and agriculture (Shazoo et al., 2013).

In recent scientific literature, there has been a high emphasis on topinambur and its prospects for use in food, pharmaceutical, canning and feed production (Yang et al., 2015). The value of this plant is determined by its yield, chemical composition, unpretentiousness during cultivation. Topinambur grows in different climatic zones: from the tropics to the northern areas of agriculture (Vinogradiva et al., 2010). It is an important source of nutrition particularly in Mediterranean region. Besides this it also has significant contribution in agricultural economy of Mediterranean region where more than $60 \%$ of the global Jerusalem artichoke crop produce. Italy is the top producer of Jerusalem artichoke with 474.000 t/year. Spain is the second biggest producer with 215.000 $\mathrm{t}$ and France is the third largest producer with $55.000 \mathrm{t}$ annual production (Lattanzio et al., 2009; FAO, 2007). The highest production of Topinambur (or earth pear) due to its valuable biological potential and chemical composition can be widely used in human nutrition and health, in pharmaceuticals, in feed production, in the production of various industrial processing products (inulin, alcohol, etc.).

Jerusalem artichoke (Helianthus tuberosus L.) is being used for different purposes such as animal feed, human food and as a feedstock for bioenergy and bioproducts generation ( $\mathbf{L i}$ et al., 2013). Moreover, the crop can be grown under different environmental conditions (Rebora, 2008). It contains high concentrations of fructo-oligosaccharides and inulin (16-20\% of fresh weight) (Van Loo et al., 1999). The composition, polydispersity and chain length is dependent on many factors such as extraction process, types of plant species, harvesting time and conditions as well as post extraction method (Ronkart et al., 2007, Rubel et al., 2014). Besides this the technical and biological characteristics of inulin is also dependent on all the above mentioned factors (Roberfroid, 2005) Inulin is mixture of poly and oligosaccharides and it is a polymer of $d$ fructose which is connected with each other through $\beta(2 \rightarrow 1)$ linakges (Causey et al., 2000). Inulin frauctans units are called as probiotics because they are helpful for the development of some desirable bacteria in the colon which are helpful in improvement of human health (Bach et al., 2013, Causey et al., 2000). Topinambur is an important source of fructans: polysaccharide inulin and oligofructose, which in the human body perform the function of prebiotics, promote the growth of beneficial, as well as suppression of pathogenic and unwanted intestinal microflora, improve its motor function (Lachman et al., 2008; Yaroshevich, 2010; Zelenkov et al., 2012). Due to the rich composition of biologically active substances topinambur is a very promising raw material in feed production, dietetic nutrition and food industry, is used as an original raw material for creating highly effective biologically active additives and therapeutic and preventive drugs.

\section{Plant Characteristics}

Jerusalem artichoke (Helianthus tuberosus) is a $100-300 \mathrm{~cm}$ tall perennial plant It contains oval shaped hairy leaves, tiny flowers with yellow color and it bears small tubers through underground rhizome system. It has fibrous hairy roots which can grow up to $1.27 \mathrm{~m}$. which are helpful in nutrient acquisition as well as to tolerate environmental effects. Jerusalem artichoke is an angiosperm plant which belongs to compositae family which is generally known as sunflower or daisy family (Monti et al., 2005; Tassoni et al., 2010; Kays \& Nottingham 
2007). Jerusalem artichoke plant contains rigid and stems which become woody as they mature. The leaves of the plant start alternating from the top and the leaves at the top are narrow and smaller whereas the leaves at the bottom are broad and larger in size with up to $30 \mathrm{~cm}$ size. The width of the leaves is usually $5-7.5 \mathrm{~cm}$. The flowers are formed from tubular disk shaped tiny flowers which are covered by florets. These tiny flowers are formed in groups as well as alone at the lower part of main stems and alar branches. The tubers of Jerusalem artichoke plant are uneven which extend from knotty to round clusters (Yang et al., 2015) The tubers color varies in different verities and the color of tubers generally ranges from pale brown to white, purple and red (Duke, 1983; Griffiths \& Huxley, 1992). The crop can grow easily in wide range of $\mathrm{pH}(4.5-8.2)$ as well as different temperature levels. Moreover, the plant does not need a strict attention as well as wide use of pesticides, herbicides and insecticides (Li et al., 2009).

Before the arrivals of Europeans the Jerusalem artichoke was gown for the first time by Native Americans. It was called as sun root in the older times. After that the plant was given different common and Latin names were given to the Jerusalem artichoke. There are about hundred common names which are being used for Jerusalem artichoke round the globe (Kays \& Nottingham 2007). The commonly used names for Jerusalem artichoke in English includes wood land flower, sunchoke, eath apple and topinambur. The name "Jerusalee artichoke" which is most commonly being used is confusing because the plant belongs to the genus of garden sunflower and it is a type of sunflower. But there is no relation between Jerusalem as well as it is not a type of artichoke.

\section{Chemical Composition of Topinambur}

The proximate composition is the key index used to measure the nutritious potential of food products. The unique value of topinambur tubers is determined by its chemical composition, specifically by the presence of a wide range of functional ingredients: inulin, pectin, vitamins of group B, macro- and microelements, characterized by high technological properties (Anikienko, 2008)
The color of tubers varies from pale brown, red and purple depending upon the climate conditions (Gupta \& Chaturvedi, 2020). The tubers of topinambur contain about $25 \%$ of dry matter, the main mass of which is carbohydrates. They are mainly fructose, i.e. fructose polymers. The content of inulin in the tubers reaches $80 \%$ of dry matter (Shazzo et al., 2013).

The proximate composition of Jerusalem artichoke has been shown in Table.1. It is clear from the table that the composition of Jerusalem artichoke is comparable with potato, cassava and yams. Moreover, the fiber contents of Jerusalem artichoke are higher and fat contents are lower than that of other tubers which makes it as a good alternative of these foods. The carbohydrate contents of Jerusalem artichoke are a little bit lower that potato, cassava and yams but it is within the range of FAO standard. The tubers of topinambur contain a unique carbohydrate complex based on fructose and its polymers, the highest homologist of which is inulin. Inulin is the most valuable and quantitatively predominant carbohydrate component (Szewczyk et al., 2019). The high content of inulin in tubers allows using topinambur as a source material for diabetic food: flour, juice, syrup, confectionery and bakery products. Inulin and dietary fiber can sorb a significant amount of food glucose and prevent its absorption into the blood, which helps to reduce blood sugar levels. The use of topinambur causes a significant reduction in cholesterol levels. Inulin causes intensive growth of bifidobacteria in the body, prevents the development of pathogenic microflora, promotes the rehabilitation of the disturbed activity of the gastrointestinal tract (Zelenkov, 2001; Kaszás et al., 2020)

Polysaccharides, which are part of the cell membranes of tubers' tissues (food fibers), are in the second place after inulin in quantitative relation. Pectins and dietary fibers have a therapeutic effect in the treatment of diseases of the gastrointestinal tract, which determines the use of products from topinambur in therapeutic and preventive nutrition (Zhang et al., 2015; Akram et al., 2020; Kakimov et al., 2021).

Table 1 Chemical composition of Topinambur (\% g/100 g)

\begin{tabular}{|c|c|c|c|c|c|c|c|c|}
\hline & $\begin{array}{l}\text { Jerusalem } \\
\text { artichoke }\end{array}$ & Reference & Potato & Reference & Cassava & Reference & Yams & Ref \\
\hline Moisture & 75.4 & Puyanda et al., 2020 & 71.7 & Alam et al., 2016 & 70.19 & Mohan et al., 2019 & 69.5 & Bhandari et al., 2003 \\
\hline Crude Protein & 2.4 & Puyanda et al., 2020 & 3.15 & Alam et al., 2016 & 0.85 & Mohan et al., 2019 & 3.1 & Bhandari et al., 2003 \\
\hline Crude Fat & 0.09 & Puyanda et al., 2020 & 0.28 & Alam et al., 2016 & 0.25 & Mohan et al., 2019 & 0.3 & Bhandari et al., 2003 \\
\hline Ash & 0.7 & Puyanda et al., 2020 & 1.22 & Alam et al., 2016 & 2.99 & Mohan et al., 2019 & 1.2 & Bhandari et al., 2003 \\
\hline Carbohydrates & 21.3 & Puyanda et al., 2020 & 23.21 & Alam et al., 2016 & 0.09 & Mohan et al., 2019 & 1.1 & Bhandari et al., 2003 \\
\hline inulin & 72.18 & Munim et al., 2017 & & Alam et al., 2016 & 25.63 & Mohan et al., 2019 & 25.9 & Bhandari et al., 2003 \\
\hline
\end{tabular}

\section{Mineral Contents of Jerusalem artichokes}

Mineral contents of Jerusalem artichokes has been shown in Fig.1 and Fig.2 respectively. It is clear from the figure that potassium is found in highest concentrations followed by phosphorous, magnesium, calcium and Sulphur. The average values macro elements in of Jerusalem artichokes are comparable with previous values found by Florkiewicz et al. (2007). One of the important features of topinambur is its balanced macro- and microelement composition - it contains a large amount of phosphorus $(3892 \mathrm{mg} / \mathrm{kg}$ dry matter) and potassium ( $23356 \mathrm{mg} / \mathrm{kg}$ dry matter). Topinambur contains: iron $-39.22 \mathrm{mg}$; Zinc -13.56 $\mathrm{mg}$; calcium $-1864 \mathrm{mg}$, which is essential for diabetes mellitus patients (Tokarev, 2018; Koltsov and Akimov, 2015)

The content of copper in topinambur tubers $7.18 \mathrm{mg} / 100 \mathrm{~g}$, magnesium contents is $1897 \mathrm{mg} / 100 \mathrm{~g}$, Sulphur content is $616 \mathrm{mg} / 100 \mathrm{~g}$, copper contents is 7.18 $\mathrm{mg} / 100 \mathrm{~g}$, potassium contents is $23356 \mathrm{mg} / 100 \mathrm{~g}$, iron contents $39.22 \mathrm{mg} / 100 \mathrm{~g}$, zinc contents $13.56 \mathrm{mg} / 100 \mathrm{~g}$ (Kochnev and Kalinicheva, 2002; Harmankaya et al., 2012).

It is known that dried tubers of topinambur contain increased content of silicon (up to $8 \%$ per ash residue), potassium up to $2000 \mathrm{mg} \%$, iron and other macroand microelements (Nikolaevich, 2000).

The ash contents of topinambur are also in line with other starch tubers and roots. Magnesium is helpful in lowering blood pressure, can provide strength to bones and for better heart function. Phosphorous is helpful in bone and teeth development by combination with calcium and also aids in quick release of energy in human body. It is clear from the composition of tiger nuts they contain relatively lower amounts of sodium and calcium. A recent study has shown that a diet rich in magnesium and potassium and have lower concentrations of sodium can be helpful in lowering blood pressure (Wardkaw, 2002). Potassium and sodium are also beneficial in retaining water balance, acid balance and osmosis conservation. Potassium is also helpful for carbohydrates and protein metabolism. It is also beneficial in protecting the internal arterial walls. Moreover, it is helpful in controlling heart attack and haemorrhages (Oladele et al., 2009). Zinc also play a major role in many metabolic reactions such as alcohol metabolism. It is also helpful in boosting immune system, reproduction and sexual development. Tiger nuts also contain iron which is also helpful in metabolism of iron. The topinambur actively accumulates silicon from the soil. In tubers, the content of this element is up to $0.8 \%$ per dry matter. Potassium, iron, and phosphorous predominate among minerals. The high content of zinc, silicon, potassium in the topinambur helps the synthesis of its own insulin by special cells of the pancreas. Because of the high iron content, tubers are recommended to be consumed in case of anemia (Belyaeva and Panarina, 2016).

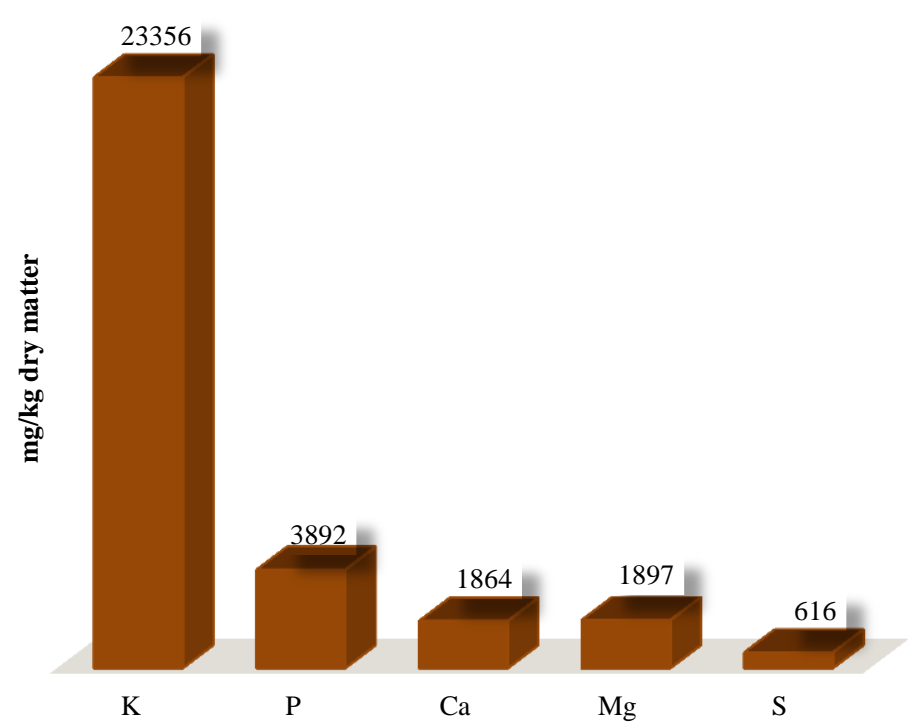

Figure 1 Macro Elements concentration of Jerusalem artichokes 


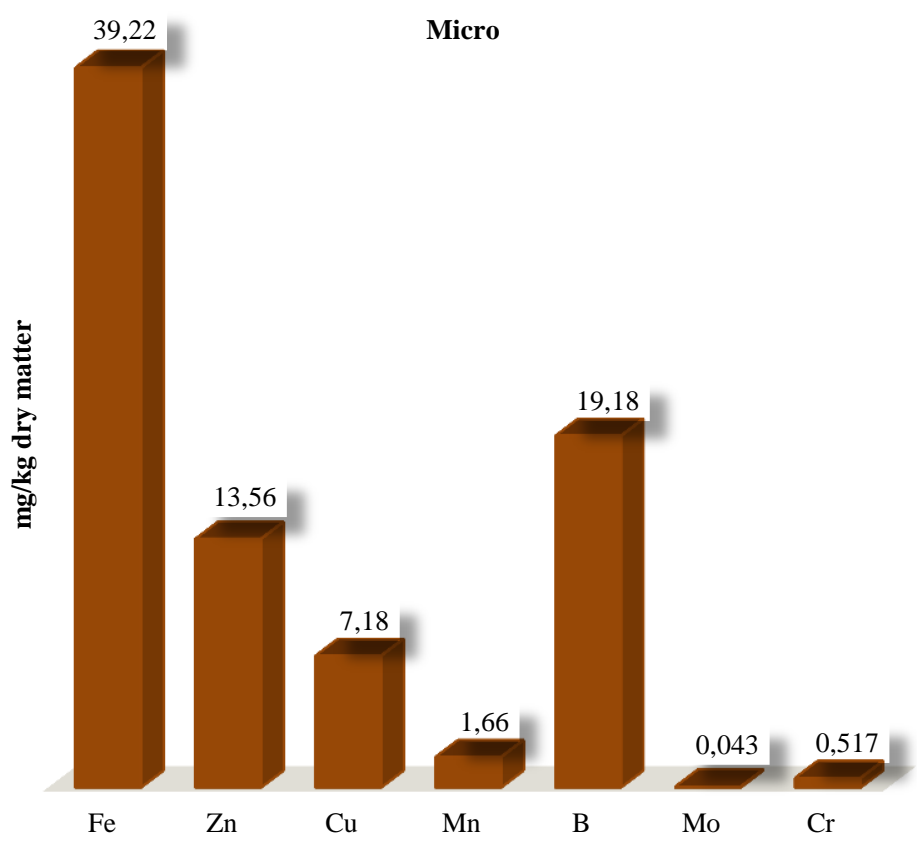

Figure 2 Micro Elements concentration of Jerusalem artichokes

The use of topinambur in the recipe has a number of advantages, one of which is its significant content of inulin - a sugar substitute. Inulin is a polysaccharide, hydrolysis of which leads to the production of fructose, a harmless sugar for diabetics. Topinambur tubers also contain proteins, pectin, amino acids, organic and fatty acids. Pectin substances in topinambur contain up to $11 \%$ of dry matter mass, and by the content of vitamins "B1", "B2", "C" topinambur is more than three times richer than potatoes, carrots and beets. A significant difference of topinambur from other vegetables is the high content of protein in its tubers (up to $3.2 \%$ per dry matter), represented by eight amino acids, including essential: arginine, valine, histidine, isoleucine, leucine, lysine, methionine, threonine, tryptophan, phenylalanine (Zelenkov and Shain, 2000; Pavlova, 2014).

The vitamin composition of topinambur tubers is characterized by a high content of B vitamins, carotenes and ascorbic acid. Thus, according to the reference data (Kaldly et al., 1980) the topinambur, except vitamin PP $(0.27 \mathrm{mg} / 100 \mathrm{~g})$, contains vitamins B2 $(7.3 \mathrm{mg} / 100 \mathrm{~g})$, vitamin C $(120.5 \mathrm{mg} / 100 \mathrm{~g})$. Most of these vitamins are preserved during treatment. Table 2 and 3 depict vitamins and amino acid profile of topinambur.

Table 2 Vitamin Composition of Topinambur (Sadykov, 2009).

\begin{tabular}{lc}
\hline Vitamin & Content \\
\hline Vitamin E (tocopherol), $\mathrm{mg} / \mathrm{kg}$ & 3.0 \\
Vitamin B1 (thiamine), $\mathrm{mg} / \mathrm{kg}$ & 0.15 \\
Vitamin B2 (ribovlaphin), $\mathrm{mg} / \mathrm{kg}$ & 0.2 \\
Vitamin B3 (pantothenic acid), $\mathrm{mg} / \mathrm{kg}$ & 0.8 \\
Vitamin B4 (choline), mg/kg & 280.0 \\
Vitamin B5 (nicotinic acid), $\mathrm{mg} / \mathrm{kg}$ & 2.4 \\
\hline
\end{tabular}

Table 3 Aminoacid Composition of Topinambur, g/100g of protein (Matveeva, \& Koryachkina, 2012).

\begin{tabular}{lcc}
\hline Aminoacid & Content & Reference \\
\hline Valine & 3.91 & 18 \\
Isoleucine & 4.52 & 18 \\
Leucine & 6.63 & 18 \\
Lysine & 5.94 & 18 \\
Methionine + Cysteine & 2.23 & 18 \\
Threonine & 3.43 & 18 \\
Phenylalanine + Tyrosine & 6.15 & 18 \\
\hline
\end{tabular}

In the modern concept of healthy eating special role belongs to the products of functional purpose, neutralizing the adverse effects of the environment and unbalanced nutrition. Topinambur is a very promising raw material for prebiotic and dietary nutrition. Inulin, as a reserve polysaccharide, makes up to $75 \%$ of topinambur carbohydrate complex. It is considered an effective remedy in the treatment of diabetes, atherosclerosis, obesity and various intoxications (Zhuchkova and Skripnikova, 2017).

Topinambur is a source of natural substances with carbohydrate metabolism and expressed properties of prebiotics, such as polysaccharides of inulin nature.
Fructose-containing polysaccharide inulin has a low glycemic index, which is widely used for therapeutic nutrition.

\section{Pharmacological effect of topinambur}

Topinambur has a multipurpose therapeutic properties. It is used in the production of highly effective drugs to correct metabolism in diabetes, atherosclerosis, obesity, kidney, liver, cardiovascular system, gastrointestinal tract diseases. For the human body, topinambur is the "supplier" of fructose, and is an excellent agent for the prevention of diabetes, because consumption of fructose instead of sucrose reduces the likelihood of this serious disease. Topinambur is recommended for use in cardiovascular diseases such as anemia hypertension, arrhythmias, circulatory disorders. It helps strengthen the nervous system after severe stress, and also has diuretic and laxative properties. Topinambur is necessary to eat for people suffering from heartburn and promotes the treatment of gastritis with high acidity. It can also be used for preventive treatment of gastric and duodenal ulcers (Leonid et al., 1999; Radovanovic et al., 2015)

The benefits of topinambur in decreasing cholesterol, maintaining healthy intestinal microflora, suppressing intestinal infection, combating obesity, maintaining blood sugar levels in diabetic patients and improving blood lipid composition have been firmly established (Hidaka et al., 2001).

Furthermore, inulin and fructo-oligosaccharide supplements can boost the immune system and help in preventing a wide range of diseases such as ulcerative colitis, inflammatory bowel diseases and colon cancer (Hidaka et al., 2001; Pool-Zobel et al., 2002).

The topinambur contains higher concentrations of $\mathrm{K}^{+}$ions and a low $\mathrm{Na}^{+} / \mathrm{K}^{+}$ratio as compared to other vegetables which is helpful for prevention of cardiovascular and hypertension diseaseases (Pandino et al., 2011). Inulin isaprimary component of topinambur which is helpful in $\mathrm{Ca}$ absorption which improve the metabolism of lipids. It also has the anti-cancer properties (LopezMolina $\boldsymbol{e t}$ al. 2005; Sonnante et al., 2007; Lattanzio et al., 2009). Tpinambur is known to have hepatostimulant and diuretic effects since ancient times. Recently it has also been observed to contain bioactive constituents as phenolic compounds. These phenolic compounds have been found to have pharmacological activities like cholesterol inhibition, anti-HIV, anti-oxidant, anti-atherosclerotic, antcarcinogenic, anti-bacterial, hepato-protective and urinative (Ceccarelli $\boldsymbol{e t}$ al. 2010; Fantini et al., 2012; Osama et al., 2014).

Nutritional purpose of topinambur is closely related to its therapeutic use in folk medicine. It has a beneficial effect on the human body during stress, loss of strength, intoxication, coronary heart disease, anemia (anemia), tuberculosis, diseases of the gastrointestinal tract with increased acidity, constipation, skin diseases, pyelonephritis, osteochondrosis and burn injuries. It is widely used as an effective cosmetic tool (Ma et al., 2011; Epanchina et al., 2020).

Water soluble vitamins

Water soluble vitamin contents of topinambur has been presented in table.2 (Catana et al., 2018). The water soluble vitamin contents of topinambur are comparable with (Izembaeva $\boldsymbol{e t}$ al., 2013) These vitamins are important for proper growth of human as well as they are effective in controlling different chronic diseases. A previous study of Harvard showed that the one addition of fruits and vegetables in food helps in controlling cardiovascular diseases (Hussein et al., 1999). Thianin is helpful for the metabolism of carbohydrates, $\alpha$ keto acids decarboxylation as well as transfer of active aldehydes. The requirements of thiamin is dependent on the intake of carbohydrates. As the carbohydrates intake increases its requirement also increase (NRC, 1989). Niacin is also an important enzymes which is required by hundreds of enzymes as a cofactor. The enzymes which are involved in energy metabolism utilize this vitamin. Pantothenic $\left(B_{5}\right)$ is required for coenzymes synthesis, metabolism of proteins, fatty acids, carbohydrates and proteins. Its requirement is $1.7-7 \mathrm{mg} / \mathrm{day}$ for the human beings. Its deficiency may cause nervous disorders, immune system disorder as well as reduced growth rate. Pyridoxine $\left(\mathrm{B}_{6}\right)$ is also an important vitamin which require for the metabolism of amino acids as well as it is helpful for controlling the deficiency of red blood cells (anemia). Vitamin C is also known as ascorbic acid. It is an important vitamin which is helpful for cells protection, for proper health of skin, bones and blood vessels and healing of wounds (NRC, 1989). It is clear from the above discussion that all the water soluble enzymes are important for human health and it is evident from table.2 that topinambur contain significant amount of these vitamins and can be helpful as a water soluble vitamin source (Table 4)

Table 3 Water soluble vitamins contents of topinambur $(\mathrm{mg} / 100 \mathrm{~g})$

\begin{tabular}{ccccc}
\hline Thianin & Niacin & $\begin{array}{c}\text { Pantothenic } \\
\mathbf{B}_{\mathbf{5}}\end{array}$ & $\begin{array}{c}\text { Pyridoxine } \\
\mathbf{B}_{\mathbf{6}}\end{array}$ & Vitamin C \\
\hline $0.198 \pm 0.04$ & $1.121 \pm 0.161$ & $0.227 \pm 0.011$ & $0.0738 \pm 0.0069$ & $2.542 \pm 0.123$ \\
\hline
\end{tabular}

\section{Amino Acids}

The average concentrations of amino acids in Jerusalem artichokle has been shown in table.3. It is clear from the table that Jerusalem artichoke contain almost 
all the essential as well as non-essential amino acids and the arginine which is an essential amino acid is found in highest concentration in Jerusalem artichoke. This amino acid is necessary for protein production in the body and it fish, poultry, red meat and dairy products are a good source of this essential amino acids. It is helpful for release of hormones, chest pain, ammonia removal from the body, high blood pressure, wound healing, as well as intestinal disease in premature infants. Moreover, the Jerusalem artichoke contain highe concentrations of sulphur amino acids. It was previously observed that it contain four times higher concentrations of sulphur amino acids compared to chicory and potato (Cieślik et al., 2011). Therefore it can be used with legume seeds which contain poor concentrations of these amino acids. Moreover it can also be used as a cheaper source of protein in Asian countries where soy bean is mainly used as a protein source. Similarly, methionine is also an essential amino acid and is important in the growth of new blood vessels. This amino acids is helpful for those people who are suffering from copper poisoning. This amino acids is restrictive in green vegetables and potatoes and hence Jerusalem artichoke can be incorporated in food with potatoes and green vegetables to fulfill the deficiency of this amino acid. Besides these two amino acids it also contain all the essential amino acids two times more compared two potato and chicory. Chicory is an industrial source of fructans and similarly potato is also most commonly used al over the world as a vegetable. Jerusalem artichoke can be incorporated in meals not only to increase the variety but to supplement all the essential amino acids in foods (Table 5).

Table 5 Amounts of amino acids in Jerusalem artichoke $(\mathbf{m g} / \mathbf{1 0 0 g})(\mathbf{L e e}, \mathbf{2 0 1 6}$ Wang et al., 2020: Cieślik et al., 2011)

\begin{tabular}{ll}
\hline Amino Acid & Content $\mathbf{( m g} / \mathbf{1 0 0 g})$ \\
\hline Asp & 288.9 \\
Thr & 154.6 \\
Ser & 180.1 \\
Glu & 264.5 \\
Pro & 107.8 \\
Gly & 237.1 \\
Ala & 77.8 \\
Val & 138.9 \\
Met & 56.2 \\
Ile & 77.5 \\
Leu & 88.1 \\
Tyr & 104.6 \\
Phe & 78.1 \\
Lys & 97.1 \\
His & 62.9 \\
Arg & 1744.4 \\
\hline
\end{tabular}

\section{Phenolic Contents}

Tchoné et al., 2006 determined the concentration of phenolic compounds in nine different verities of Jerusalem artichoke. The average concentration of twenty two phenolic compounds with their melting points has been shown in Table. It was determined that out of these 22 phenolic 15 were observed for the first time The fifteen newly detected phenolic compounds includes ellagic acid, gallic acid, salicylic acid, sinapic acid, protocatechuic acid, syringic acid, umbelliferon, esculin, 4-hydroxycumarin, 2-hydroxy-3-5-dinitrobenzoic acid, 3hydroxycinnamic acid, catechin, scopoletin, cumaric-3-carbonic acid and epicatechin. Salicylic acid was found in highest concentration and regarded as the main phenolic compound. It was also observed that the concentration of phenolic compounds depends on the growth period of Jerusalem artichoke and the phenolic concentrations increase with the growth of Jerusalem artichoke Moreover, the concentrations of phenolic compounds reached at maximum point with the development of plant and then decreased. It was also observed that the concentration of phenolic compounds in Jerusalem artichoke depends on many factors including verity, $\mathrm{pH}$ of the tubers, chemical structures, moisture contents, specific electrical conductability and degree of the metabolism activation.

Besides 2-hydroxy-3-5-dinitrobenzoic acids and cumarin-3-carbonic all the phenolic compounds detected in Jerusalem artichoke have the antioxidant as well as bioactive potential. Meyer and co-workers (Meyer et al., 1998 a, b) determined the antioxidant activity of chlorogenic acids, catechin, ferulic, caffeic, p-coumaric and ellagic. Foti and co-workers (Foti et al. 1996) determined the antioxidant potential of 4-hydroxycoumarin, scopoletin and umbelliferon. Tannins such as cathechin and gallic acid also have the antioxidant potential
(Chuang-Ye et al. 1995, TAKUO et al. 1983, RIGO et al. 2000). Moreover, it was also observed that caffeic acids, gallic, protocatechuic and ferulic possess radical scavenging activity. It had been observed previously that chlorogenic acids and caffeic have stronger radical scavenging capacity than buthylhydroxytoluen and $\alpha$-tocopherol (Chen and Ho, 1997). Salicylic acid is found in highest concentrations and it had been found that this phenolic has antimicrobial potential against many microbes such as Bacillussubstilis IAM 1521, E. coli K12AM and Staphylococcus aureus IAM101 (Nguyen et al., 1982). The sinapic acid also found to have strong antimicrobial activity especially against E-Coli due to its hydroxyl and methoxyl groups (Tesaki et al. 1998) (Table 6).

Table 6 detected phenolic compounds in topinambur

\begin{tabular}{|c|c|c|}
\hline Phenolic Compound & $\begin{array}{l}\text { Melting-point } \\
\text { in }{ }^{\circ} \mathbf{C}\end{array}$ & $\begin{array}{l}\text { Content (g phenolic } \\
\text { compound } / 100 \text { g skin } \\
\text { dry weight) }\end{array}$ \\
\hline Gallic acid & $255-265$ & $0.032 \pm 0.03$ \\
\hline Protocatechuic acid & $202-204$ & $0.121 \pm 0.03$ \\
\hline Esculin & 200 & $0.162 \pm 0.05$ \\
\hline Gentisic acid & $202-206$ & $0.895 \pm 0.6$ \\
\hline Catechin & 200 & $0.085 \pm 0.07$ \\
\hline 4-hydroxybenzoic acid & $212-215$ & $0.038 \pm 0.02$ \\
\hline Chlorogenic acid & $203-205$ & $1.515 \pm 1.15$ \\
\hline Vanillic acid & $208-210$ & $0.088 \pm 0.1$ \\
\hline Syringic acid & 204-207 & $0.0141 \pm 0.01$ \\
\hline Caffeic acid & $234-237$ & $0.08 \pm 0.07$ \\
\hline Epicatechin & $240-245$ & $0.39 \pm 0.17$ \\
\hline $\begin{array}{l}\text { 2-hydroxy-3-5- } \\
\text { dinitrobenzoic acid }\end{array}$ & $170-174$ & $0.0544 \pm 0.04$ \\
\hline $\begin{array}{l}\text { Umbelliferon ( } 7- \\
\text { hydroxycumarin) }\end{array}$ & $226-229$ & $0.0816 \pm 0.01$ \\
\hline $\begin{array}{l}\text { Scopoletin (7-hydroxy-6- } \\
\text { methoxycumarin) }\end{array}$ & $204-206$ & $0.05 \pm 0.02$ \\
\hline p-cumaric acid & $219-222$ & $0.024 \pm 0.008$ \\
\hline Cumarin-3-carbonic acid & $188-191$ & $0.011 \pm 0.01$ \\
\hline Ferulic acid & $169-175$ & $0.019 \pm 0.01$ \\
\hline Sinapic acid & $195-200$ & $0.0322 \pm 0.02$ \\
\hline 3-hydroxycinnamic acid & $193-195$ & $0.00256 \pm 0.003$ \\
\hline Ellagic acid & $>350$ & $0.0258 \pm 0.009$ \\
\hline Salicylic acid & $158-161$ & $3.887 \pm 1.24$ \\
\hline 4-hydroxycumarin & $211-214$ & $0.193 \pm 0.06$ \\
\hline
\end{tabular}

\section{Volatile Compounds}

The volatile compounds concentrations in Jerusalem artichoke tubers had been tested by different scientists previously. MacLeod et al. (1982) used trichlorofluoromethane for extraction of volatile compounds from Jerusalem artichoke tubers and the results indicates 52 volatile compounds. Most of the detected compounds were high-boiling hydrocarbons and they were unidentified Bach et al., 2012 detected 41 compounds in Jerusalem artichoke tubers out of which 31 compounds were identified by NIST database as well as mass spectral data and comparison of linear retention indices. The concentrations of the detected compounds were very low and only 16 compounds were quantified which are shown in table.4. The total concentration of volatile compounds was found to be $25.5 \mathrm{ng} / \mathrm{g}$ fresh weight. It is also clear from the table that $\beta$ Bisabolene volatile compound which belong to sesquiterpene chemical group was found in highest concentration (53.97 $\mathrm{ng} / \mathrm{g}$ fresh weight). $\alpha$-Pinene is the second most abundant volatile compound with $38.9 \mathrm{ng} / \mathrm{g}$ fresh weight concentration. Hexanal which is an aldehyde ranks third in concentration with $1.13 \mathrm{ng} / \mathrm{g}$ fresh weight (Table 7).

The percentage share of different chemical groups in volatile compounds of Jerusalem artichoke tubers has been shown in Figure 4. It is clear from the fig that sesquiterpene group has the largest share of $57 \%$ in volatile compounds. The monoterpene is the second largest chemical group with $40 \%$ share in the volatile compounds. Aldehydes ranks third in percentage share of volatile compounds with $1 \%$ contribution whereas all other chemical groups are found to be less than $1 \%$ share. 
Table 7 Concentrations of volatile compounds isolated from Jerusalem artichoke tubers (ng/g fresh weight) (Bach et al., 2012)

\begin{tabular}{|c|c|c|c|c|}
\hline Volatile compound & Chemical Group & $\begin{array}{c}\text { Concentrations (ng/g fresh } \\
\text { weight) }\end{array}$ & Percentage of total (\%) & Odour \\
\hline$\alpha$-Pinene & Monoterpene & $9.9 \pm 8.2$ & 38.9 & Carrot top, Pine \\
\hline Hexanal & Aldehyde & $0.3 \pm 0.1$ & 1.13 & Fat, Green, Grassy \\
\hline Sabinene & Monoterpene & $0.23 \pm 02$ & 0.91 & $\begin{array}{l}\text { Fresh green pepper, } \\
\text { Carrot-like, }\end{array}$ \\
\hline 1-Butanol & Alcohol & $0.033 \pm 0.04$ & 0.13 & Solvent-like, Malty \\
\hline 1-Pentene-3-ol & Alcohol & $0.044 \pm 0.06$ & 0.17 & $\begin{array}{l}\text { Mild grassy, green, } \\
\text { pungent }\end{array}$ \\
\hline Dodecane & $\begin{array}{l}\text { Aliphatic } \\
\text { hydrocarbon }\end{array}$ & $0.03 \pm 0.04$ & 0.13 & Alkane \\
\hline 2-Methyl-1-butanol & Alcohol & $0.3 \pm 0.2$ & 1.00 & $\begin{array}{l}\text { Cooked, roasted, } \\
\text { wine }\end{array}$ \\
\hline 1-Hexanol & Alcohol & $0.1 \pm 0.08$ & 0.39 & Flower, green, resin \\
\hline Sesquiterpene 1 & sesquiterpene & $0.14 \pm 0.08$ & 0.56 & - \\
\hline Sesquiterpene 2 & sesquiterpene & $0.2 \pm 0.07$ & 0.69 & - \\
\hline$\alpha$-Copaene & sesquiterpene & $0.2 \pm 0.09$ & 0.61 & $\begin{array}{l}\text { Wood, spice } \\
\text { Citrus-like, }\end{array}$ \\
\hline Linalool & Terpene alcohol & $0.02 \pm 0.04$ & 0.087 & $\begin{array}{l}\text { bergamot-like, } \\
\text { flower }\end{array}$ \\
\hline$\alpha$-Cedrene & sesquiterpene & $0.033 \pm 0.04$ & 0.13 & \\
\hline Aromatic hydrocarbon & $\begin{array}{c}\text { Aromatic } \\
\text { hydrocarbon }\end{array}$ & $0.055 \pm 0.08$ & 0.22 & \\
\hline$\beta$-Sesquiphellandrene & sesquiterpene & $0.22 \pm 0.07$ & 0.87 & \\
\hline$\beta$-Bisabolene & sesquiterpene & $13.74 \pm 3.7$ & 53.97 & \\
\hline Total & & 25.5 & & \\
\hline
\end{tabular}

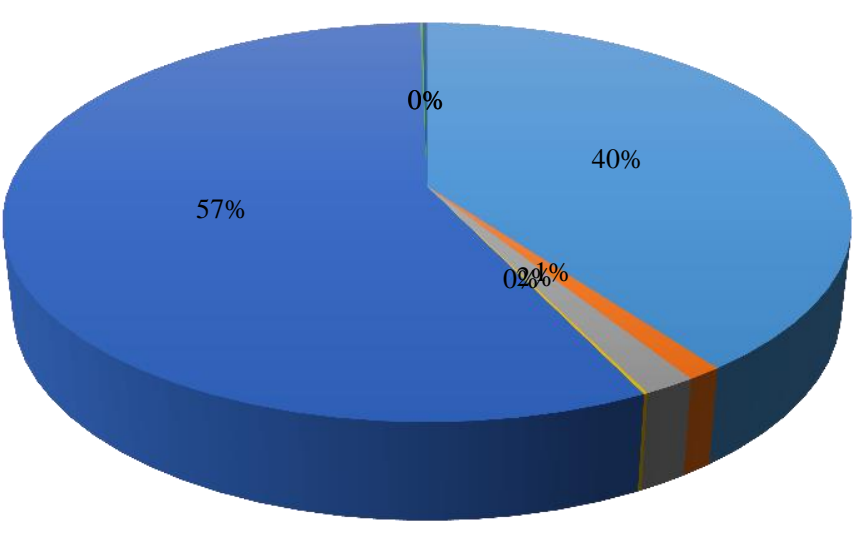

Monoterpene Aldehyde

- Alcohol

$\square$ Aliphatic hydrocarbon $\square$ sesquiterpene

Terpene alcohol

Aromatic hydrocarbon

Figure 4 Percentage share of different Chemical Groups in volatile compounds of Jerusalem artichoke tubers

\section{Using topinambur in food formulation}

\section{Using topinambur in milk products formulation}

Topinambur tubers are widely used in the preparation of milk products. Thus, the authors have developed a method of producing nonfat yogurt with the addition of the topinambur powder. The introduction of topinambur powder allows to enrich yogurt with valuable nutrients. Topinambur powder is a loose mass of light beige color with sweet taste and contains according to the analyzed data moisture $6 \%$; polysaccharides of inulin nature not less than $70 \%$; proteins $7 \%$; fats $0,3-0,5 \%$; pectin substances $8-10 \%$; fiber 6-7\%; vitamins B1, B2, C; minerals: iron to 12 $\mathrm{mg} \%$, silicon to $8 \mathrm{mg} \%$, potassium to $200 \mathrm{mg} \%$, phosphorus to $500 \mathrm{mg} \%$, calcium to $40 \mathrm{mg} \%$, magnesium to $30 \mathrm{mg} \%$, zinc to $15 \mathrm{mg} \%$, manganese to 45 mg \% (Fedorovich et al., 2013).

Polyansky and others developed a method of production of milk therapeutic and prophylactic product with the addition of topinambur. Tubers of topinambur are crushed to the size of particles 1-2 mm, and added in the amount of $14-16 \%$ to the mass of protein fraction or as a dry concentrate in the amount of 5-6\% to the mass of protein fraction. The expansion of therapeutic and prophylactic properties of the product when using topinambur as a carbohydrate supplement is due to the content of up to $20 \%$ inulin, which is a polysaccharide containing Dfructofuranosis residues of fructose. The increase of food and biological value of the product is provided by the content of protein in topinambur up to $2 \%-17$ related amino acids have been identified, among which glutamine and asparagine prevail (Polyansky et al., 1999).

Volkova et al. (2001) describe the method of production of cottage cheese mass, which consists of cottage cheese of $9 \%$ fat content, cream, sugar substitute, topinambur, which is crushed to particle size $5-7 \mathrm{~mm}$ before being introduced into the mixture, fruit and berry flavor, stabilizer. The invention allows to receive a product of the high biological value possessing dietary and treatment-andprophylactic properties due to the balanced carbohydrate, vitamin and mineral complexes. Khuenpet et al. (2020) developed yoghurt formulation with addition of Jerusalem artichoke extract and juice. Based on the results, yoghurt contained inulin $129.78 \mathrm{mg} / \mathrm{g}$ and reducing sugar $146.44 \mathrm{mg} / \mathrm{g}$.

Dried topinambur powder (from 3.0 to $5.0 \%$ ) is used in the milk dessert recipe The invention is targeted at obtaining a product with increased food and biological value, strengthening its preventive properties, providing increased antioxidant protection of the body, improving the performance of peripheral blood - reducing cholesterol and triglycerides (Andreevna et al., 2017).

In addition to topinambur powder, topinambur juice (25-35\% by weight of the product) is used in the preparation of milk drink. To prepare the drink milk whey, topinambur juice, stabilizer, sugar substitute, fruit and berry flavor and yeast are used in the preparation. The invention allows to produce a drink with prophylactic properties due to carbohydrate and vitamin complexes, to reduce the cost of the drink, to improve its organoleptic characteristics, to increase biological and food value of the drink, as well as to expand both the range of products in general and the products of dietary direction in particular. Using topinambur juice as a filler instead of chicory extract allows to significantly increase biological and nutritional value of the finished product due to balanced vitamin, carbohydrate and mineral components (Volkova et al., 1999).

Blinova et al. used topinambur tuber powder in the production of sour-milk drink with the purpose of improving its consumer properties. It was proposed to use topinambur tuber powder in the amount of 2 and $3 \%$ in the production of sourmilk drink. The sour-milk drink had a pleasant smell, a good harmonic taste, during storage no changes in organoleptic parameters were observed, and the physical and chemical parameters were within the normal range (Blinova $\boldsymbol{e t}$ al., 2017).

\section{Using topinambur in bakery products}

Radovanovic et al. (2014) developed bread with content of $75 \%$ of wheat flour and $25 \%$ of Jerusalem artichoke powder. The enriched bread contained $41.64 \%$ of water, $58.36 \%$ of dry matter, $0.27 \%$ of lipids, $8.25 \%$ of proteins, $47.64 \%$ of carbohydrates, and $6.15 \%$ of dietary fiber. The bread enriched with J. artichoke powder showed optimal nutritional and caloric value $(226 \mathrm{Kcal} / 100 \mathrm{~g}$ of bread), low glycemic index and low glycemic load values.

Ermosh et al.(2020) authors determined that introduction of 10-15\% Jerusalem artichoke powder into the recipe composition of wheat and rye-wheat bread activates the dough fermentation process, creates optimal acidity, which forms a more developed porosity, volume of finished products, slows down the staling process and increases the nutritional and prophylactic properties of the bread.

The addition of Jerusalem artichoke powder (JAP) increases the fiber content of the pastry products, making it a healthier food. The addition of Jerusalem 
artichoke powder significantly (pd0.05) influenced the amount of nonstarch polysaccharides in pastry products (Gedrovica $\boldsymbol{e t}$ al., 2011).

Mezenova and Kazakova (2010) have developed a recipe of shortbread cookies intended for diabetic nutrition, with the addition of stevia and topinambur Ponomareva et al. (2009) recommend adding topinambur cake in an amount of $15 \%$ when making rye and wheat bread. This makes it possible to improve the quality indicators of the finished product and to increase the mass fraction of dietary fiber in it by $20-25 \%$ while reducing the duration of sourdough starter and dough preparation.

Ozgoren et al. (2019) use topinambur powder instead of flour in the preparation of cookies. Adding topinambur powder from 10 to $30 \%$ to the recipe significantly increases the ash content (from $1.09 \%$ to $2.06 \%$ ), dietary fiber (from $1.86 \%$ to $9.25 \%$ ) and minerals (magnesium, calcium, potassium, phosphorus) [48]. Daina Kârkliòa et al. studied the nutritional value of biscuits with the addition of different amounts of topinambur powder. The authors determined that adding up to $50 \%$ of the powder instead of wheat flour increases the dietary fiber content to $3.98 \mathrm{~g} / 100 \mathrm{~g}$ (with the initial content of $2.41 \mathrm{~g} / 100 \mathrm{~g}$ ) and enriches inulin (up to $13.18 \mathrm{~g} / 100 \mathrm{~g})$ (Kārkliṇa et al., 2012).

\section{Using topinambur in meat products}

Isaeva et al. (2009) proposed a method of preparation of meat pate, containing beef meat, butter, milk $2.5 \%$ of fat content, with the addition of ground topinambur in the amount of 10-12 wt.\%. Adding topinambur allows to provide pate with radioprotective properties, as the pectin contained in the topinambur can remove from the body heavy metals salts, radionuclides, cholesterol.

Özer (2019) investigated the effect of topinambur powder on changes in the quality characteristics of fermented sausage. The author noted that addition of $25 \%$ of Jerusalem artichoke powder in low-fat fermented sausage production lead to the positive nutritional effects such as lower beef fat and energy value and rich dietary fiber and improve the shelf life of sausage.

Ying et al. (2015). describe the application of jerusalem artichoke whole powder and a meat product containing the jerusalem artichoke whole powder, and belongs to the field of food processes. The jerusalem artichoke whole powder can be obtained with a simple method, can be used for regulating intestinal florae and generating probiotics beneficial to a human body, and can enable people to have satiety when being eaten, thereby avoiding excess intake; the jerusalem artichoke whole powder replaces starch to be added into the meat product, so that body health of people is facilitated and the mouthfeel of the meat product further can be improved

The invention refers to the food industry, namely, the production of meat products for school, baby food, diet and therapeutic and preventive nutrition. Chopped meat products include minced beef meat, breadcrumbs and topinambur paste. The paste is obtained by combined heat treatment of topinambur tubers in convection mode $100-180^{\circ} \mathrm{C}$, humidity from dry to $100 \%$. The components are chosen in a certain quantitative ratio. It provides high nutritional value of finished products, which are well maintained in shape, have a high water-holding capacity and good organoleptic properties, as well as simplification of the technology of manufacture of products and cheapening of their cost. The use of paste from topinambur in the amount of $10 \%$ to $20 \%$ leads to the increase of water binding capacity. Paste, being mixed in minced meat at the stage of its preparation in the liquid phase, seems to increase ionic strength of the solution, increases the solubility of protein substances (Ustinova et al., 2002)

The authors developed a composition for the production of canned meat for children containing meat, starch, salt, water and additionally contains topinambu powder, soy isolate, linseed oil, caroline, vitamin E. As the meat raw materials used poultry meat, fatty pork, beef liver. The technical result is to give the product medicinal properties, specifically the properties necessary in the diet of children suffering from diseases associated with radioactive contamination of the environment (Nikolaevna et al., 2012).

The ham product described in (Kalinichenko and Shinkareva, 2017) contains rabbit meat, topinambur puree, complex food additive, pre-hydrated linseed flour, nitrite-dairy mixture, ground pepper, water/ice. The nutritional value is increased while increasing the yield of ham products from rabbit meat and while keeping the typical organoleptic characteristics of the finished product and improving the structural properties

Fegatova et al. (2017) describe the method of producing boiled-baked ham from pork. The method involves the salting of the butt by syringeing saline containing salt, color stabilizer, its massaging, maturation, rubbing with a mixture of garlic, black pepper and red pepper and heat treatment. The brine contains additionally hydrated flour of extruded germinated lentils enriched with iodine and selenium and topinambur. The biological and nutritional value of the ham is increased, the yield of the finished product is increased while keeping its organoleptic characteristics. The core of the invention in the production of boiled-baked ham is the use of vegetable raw materials - hydrated flour of extruded germinated lentils and topinambur flour. In the process of germination of lentils is enriched with iodine and selenium, and the introduction of hydrated flour extruded germinated lentils and topinambur flour is carried out in the form of a presuspension at the stage of salting by injection of a needle syringe in the meat raw material.

\section{Using topinambur in drinks}

The authors developed drinks from mashed topinambur (15-20\%) in different variants including also mashed carrot, pumpkin, apple as well as reconstituted juices - peach, passion fruit and pineapple. When developing the assortment of drinks the authors were guided by two objectives: to create a line of low-calorie vegetable drinks with the use of topinambur puree (for the target consumer); to create a delicious, harmonious product in which the specific taste of topinambur is "masked" by brighter notes of fruit additives, such as pineapple, passion fruit etc (Alabina et al., 2018)

Wenbing et al. (2013) developed the formulation and preparation method of beverage which contains a jerusalem artichoke-soybean fermentation solution as a main component. The preparation method disclosed by the invention is unique; the obtained beverage has good mouth feel, good appearance and rich nutrition; and the immunity can be improved after drinking the beverage for a long time.

Towviriyakul et al. (2012) prepared Jerusalem artichoke juice for old people particularly for those who require dietary fiber. It was observed that the juice had moderate acceptance level with a score of 5.8 out of 7 . The properties like color, sweetness and sourness were also found good and the juice thickness was found a little bit higher. It was observed that the juice is an excellent source of dietary fiber and a daily intake of $200 \mathrm{ml}$ can fulfill $35 \%$ of the dietary fibers needs of a person.

\section{CONCLUSION}

Based on the analysis of the chemical composition, nutritional and biological value of topinambur, it is concluded that this type of plant is essential for the creation and production of the healthy and highly effective therapeutic and preventive foods. Utilization of root vegetables such as Jerusalem artichoke in formulation of various food products is a good way to increase the alternative usage area of them.

\section{REFERENCES}

Alam, M. K., Rana, Z. H., \& Islam, S. N. (2016). Comparison of the proximate composition, total carotenoids and total polyphenol content of nine orangefleshed sweet potato varieties grown in Bangladesh. Foods, 5(3), 64 https://doi.org/10.3390/foods5030064

Akram, M., Riaz, M., Noreen, S., Shariati, M.A., Shaheen, G., Akhter, N., Parveen, F., Akhtar, N., Zafar, S., Owais Ghauri, A., Riaz, Z., Khan, F.S., Kausar, S., \& Zainab, R. (2020). Therapeutic potential of medicinal plants for the management of scabies. Dermatologic Therapy, 33 (1), e13186 https://doi.org/10.1111/dth.13186

Alabina, N.M., Posokina, N.E., Nariniyants, T.V., \& Davydova, A. Yu. (2018) Jerusalem artichoke-based drinks. Drinks Industry Current Issues, 2, 15 18.https://worldwide.espacenet.com/patent/search/family/047916380/publication/ CN102986893A?q=Jerusalem\%20artichoke\%2C\%20milk.

Andreevna, D.G., Alexandrovich, A.V., \& Alexandrovna, AE. (2017). Milk dessert with increased nutritional and biological value https://yandex.ru/patents/doc/RU2658607C1_20180621

Anikienko T.I. (2008). Chemical and trace element composition of tubers and green mass of Jerusalem artichoke. Bulletin of KrasGAU, 2.

Bach, V., Kidmose, U., Bjørn, G. K., \& Edelenbos, M. (2012). Effects of harvest time and variety on sensory quality and chemical composition of Jerusalem artichoke (Helianthus tuberosus) tubers. Food Chemistry, 133(1), 82-89. https://doi.org/10.1016/j.foodchem.2011.12.075

Bach, V., Jensen, S., Kidmose, U., Sørensen, J. N., \& Edelenbos, M. (2013). The effect of culinary preparation on carbohydrate composition, texture and sensory quality of Jerusalem artichoke tubers (Helianthus tuberosus L.). LWT-Food Science and Technology, 54(1),

165

170. https://doi.org/10.1016/j.lwt.2013.05.003

Belyaeva, I.A., \& Panarina, O.A. (2016). Jerusalem artichoke in preventive nutrition for diabetics // Innovative technologies in science and education: collection of articles. Art. winners Int. scientific-practical conf. 89-92.

Bhandari, M. R., Kasai, T., \& Kawabata, J. (2003). Nutritional evaluation of wild yam (Dioscorea spp.) tubers of Nepal. Food chemistry, 82(4), 619-623. https://doi.org/10.1016/s0308-8146(03)00019-0

Blinova, O. A., Trots, A. P., Romanova, T. N., \& Makushin, A. N. (2017). The use of powder from Jerusalem artichoke tubers in the production of a fermented milk drink. Advances in Modern Science, 2 (4), 176-179.

Causey, J. L., Feirtag, J. M., Gallaher, D. D., Tungland, B. C., \& Slavin, J. L. (2000). Effects of dietary inulin on serum lipids, blood glucose and the gastrointestinal environment in hypercholesterolemic men. Nutrition Research, 20(2), 191-201. https://doi.org/10.1016/s0271-5317(99)00152-9

Griffiths, M., \& Huxley, A. (Eds.). (1992). The new Royal Horticultural Society dictionary of gardening. Macmillan.

Catană, L., Catană, M., Iorga, E., Lazăr, A. G., Lazăr, M. A., Teodorescu, R. I., \& Iancu, A. (2018, July). Valorification of Jerusalem Artichoke Tubers (Helianthus Tuberosus) for Achieving of Functional Ingredient with High 
Nutritional Value. In "Agriculture for Life, Life for Agriculture” Conference Proceedings, 1(1), 276-283.

Ceccarelli, N., CuradI, M., Picciarell, P., Martelloni, L., Sbrana, C., \& Giovanneti, M. (2010). Globe artichoke as functional food. Mediterranean Journal of Nutrition and Metabolism, 3, 197-201. https://doi.org/10.1007/s12349-010-0021-z

Chen, J. H., \& Ho, C. T. (1997). Antioxidant activities of caffeic acid and its related hydroxycinnamic compounds. Journal of Agricultural and Food Chemistry, 45, 2374-2378. https://doi.org/10.1021/jf970055t

Chuang-Ye, W., Chein-Ping, W., Shian-Suo, H., \& Feng-Lin, H. (1995). The inhibitory effect of tannins on lipid peroxidation of rat heart mitochondria. Journal of Pharmacy and Pharmacology, 47, 138-142. https://doi.org/10.1111/j.2042-7158.1995.tb05766.x.

Cieślik, E., Gębusia, A., Florkiewicz, A., \& Mickowska, B. (2011). The content of protein and of amino acids in Jerusalem artichoke tubers (Helianthus tuberosus L.) of red variety Rote Zonenkugel. ACTA Scientiarum Polonorum Technologia Alimentaria, 10(4), 433-441.

Duke, J. A. (1983). Handbook of energy crops. Handbook of Energy Crops.

Ermosh, L. G., Safronova, T. N., \& Prisuhina, N.V. (2020). Features of biotechnological processes of bread production enriched with inulin-containing raw materials. IOP Conference Series: Earth and Environmental Science, 421 (2), 421

Epanchina, M. V., Knacheryan, A. V., \& Melkonyan, N. K. (2020). Jerusalem artichoke-healing root crop. in international scientific readings named after academician ad Sakharov, 33-36.

F.A.O. (2007). Statistical Database. [Online] Availabe: http://faostat.fao.org

Fantini, N., Colombo, G., Giori, A., Riva, A., Morazzoni, P., Bombardelli, E., \& Carai, M. A. M. (2011). Evidence of glycemia-lowering effect by a Cynara scolymus L. extract in normal and obese rats. Phytotherapy Research, 25, 463 466. https://doi.org/10.1002/ptr.3285

Fedorovich, G.I., Mikhailovich, O.I., Evgenievna, B.S., Sergeevna, P.M., Vasilievna, T.N., \& Aleksandrovna, V.E. (2013). using only microorganisms of the species lactobacteriaceae; yogurt http://www.freepatent.ru/patents/2490917 Fegatovna, G.L., Aleksandrovna, G.T., Vazhaevna, M.I., Anatolyevna, S.E. Fedorovich, G.I., Nikolaevna, K.V., \& Anatolyevna, K.A., Ivanovna, S.M (2017). Method for Producing Booked Pork Loin https://yandex.ru/patents/doc/RU2644016C1_20180207.

Foti, M., Piattelli, M., Barata, M. T., \& Ruberto, G. (1996). Flavonoids, coumarins, and cinnamic acids as antioxidants in a micellar system. Structure activity relationship. Journal of Agricultural and Food Chemistry, 44, $497-$ 501. https://doi.org/10.1021/if950378u

Gedrovica, I., Karklina, D., Fras, A., Jablonka, O., \& Boros, D. (2011). The nonstarch polysaccharides quantity changes in pastry products where Jerusalem artichoke (Helianthus tuberosus L.) added. Procedia Food Science, 1, 1638-1644. Gupta, D., \& Chaturvedi, N. (2020). Prebiotic Potential of underutilized Jerusalem artichoke in Human Health: A Comprehensive Review. International Journal of Environment, Agriculture and Biotechnology, 5(1): 97-103.

Hidaka, H., Adachi, T., \& Hirayama, M. (2001). Development and Beneficial Effects of Fructo-Oligosaccharides (Neosugar $\left.{ }^{\circledR}\right)$. Advanced Dietary Fibre Technology, 471-479.

Hussein, S., Hussein, B.L., \& Bruggeman, J. (1999). Selenium analysis of selected Egyptian foods and estimated daily intakes among a population group Food Chemistry, 65, 527-532. https://doi.org/10.1016/s0308-8146(98)00080-6 Isaeva, K.S., Sarlybaeva, L.M., Mukhamedzhanova, A.S., Kazhibaeva, G.T. (2009). Composition for the preparation of meat and vegetable pate. [Patent RK 28791]

Izembaeva A.K., Muldabekova B.Zh., Iataev A.I., \& Zhienbaeva S.T. (2013) The use of compositemixtures in the production of biscuits. Bulgarian Journal of Agricultural Science, 19, 28-31.

Kakimov, A., Muratbayev, A., Zharykbasova, K., Amanzholov, S., Mirasheva, G., Kassymov, S., Utegenova, A., Jumazhanova, M., \& Shariati, M. A. (2021) Heavy metals analysis, GCMS-QP quantification of flavonoids, amino acids and saponins, analysis of tannins and organoleptic properties of powder and tincture of Echinacea purpurea (L.) and Rhapónticum carthamoídes. Potravinarstvo Slovak Journal of Food Sciences, 15, 330-339. https://doi.org/10.5219/1476

Kaldy, M.S., Johnston, A., \& Wilson, D.B. (1980). Nutritive value of Indian bread-root, squaw-root, and Jerusalem artichoke. Econ Bot, 34, 352-357.

Kalinichenko, O.A., \& Shinkareva, S.V. (2017). Ham product of rabbit meat 2017. https://yandex.ru/patents/doc/RU2178978C2_20020210

Kalinichenko, O.A., \& Shinkareva, S.V. (2017). Ham product of rabbit meat. https://patents.google.com/patent/RU2643254C1/ru

Kārklina, D., Gedrovica, I., Reca, M., \& Kronberga, M. (2012). Production of biscuits with higher nutritional value. In Proceedings of the Latvian Academy of Sciences. Section B. Natural, Exact, and Applied Sciences, 66 (3), 113-116.

Kaszás, L., Alshaal, T., El-Ramady, H., Kovács, Z., Koroknai, J., Elhawat, N., Nagy, É., Cziáky, Z., Fári, M., \& Domokos-Szabolcsy, É. (2020). Identification of bioactive phytochemicals in leaf protein concentrate of jerusalem artichoke $\begin{array}{lllll}\text { (Helianthus tuberosus } & \text { 1.). } & \text { Plants, } & 9 & \text { (7), }\end{array}$ https://doi.org/10.3390/plants9070889
Kays, S. J., \& Nottingham, S. F. (2007). Biology and chemistry of Jerusalem artichoke: Helianthus tuberosus L. CRC press.

Kochnev, N.V., \& Kalinicheva, M.V. (2002). Jerusalem artichoke. Bioenergetic culture of the 21st century / N.V. Kochnev. - Moscow: Publishing house. ARES 78 p (in Russian).

Koltsov, V.A., \& Akimov, M.Y. (2015). Jerusalem artichoke tubers are a valuable source of macro and microelements in the nutrition of the population // Eurasian Union of Scientists. 7 (16), 16-18.

Khuenpet, K., Truong, N.D.P., \& Polpued, R. (2020). Inulin extraction from Jerusalem artichoke (Helianthus tuberosus L.) tuber powder and its application to yoghurt snack. International Journal of Agricultural Technology, 16 (2),271-282. Lachman, J. Kays, S.J., \& Nottingham, S.F. (2008). Biology and Chemistry of Jerusalem Artichoke Helianthus tuberosus L. Biologia Plantarum, 3(52), 492 492. https://doi.org/10.1007/s10535-008-0095-3

Lattanzio, V., Kroon, P. A., Linsalata, V., \& Cardinali, A., (2009). Globe artichoke: a functional food and source of nutraceutical ingredients. Journal of Functional Food, 1, 131-144. https://doi.org/10.1016/j.jff.2009.01.002

Lee, Y. R. (2016). Analysis of nutritional components and antioxidant activity of roasting Wooung (Burdock, Arctium lappa L.) and Jerusalem artichoke (Helianthus tuberosus L.). The Korean Journal of Food and Nutrition, 29(6), 870-877. https://doi.org/10.9799/ksfan.2016.29.6.870

Leonid, D. B., Gulyi, I. S., Remeslo, N. V., Yefimov, A.S., Melnik, I.M., Vysotskiy, V.G. (1999). Prophylactic and curative foodstuffs from topinambur, Proc. SPIE 3543, Precision Agriculture and Biological Quality. https://doi.org/10.1117/12.336904

Li, S. Z., \& Chan-Halbrendt, C. (2009). Ethanol production in (the) People's Republic of China: potential and technologies. Applied Energy, 86, 162169. https://doi.org/10.1016/j.apenergy.2009.04.047

Li, L., Li, L., Wang, Y., Du, Y., \& Qin, S. (2013). Biorefinery products from the inulin-containing crop Jerusalem artichoke. Biotechnology letters, 35(4), 471477. https://doi.org/10.1007/s10529-012-1104-3

Lopez-Molina, D., Navarro-Martinez, M. D., Melgarejo, F. R., Hiner, N. P. Chazarra, S., \& Rodriguez-Lopez, J. N. (2005). Molecular properties and prebiotic effect of inulin obtained from artichoke (Cynara scolymus L.). Phytochemistry,

1476-1484

https://doi.org/10.1016/j.phytochem.2005.04.003

Ma, X. Y., Zhang, L. H., Shao, H. B., Xu, G., Zhang, F., Ni, F. T., \& Brestic, M (2011). Jerusalem artichoke (Helianthus tuberosus), a medicinal salt-resistant plant has high adaptability and multiple-use values. Journal of Medicinal Plants Research, 5(8), 1272-1279.

Matveeva, T.V., \& Koryachkina S.Y. (2012). Physiologically functional food ingredients for bakery and confectionery products: monograph. Oryol: FGBOU VPO "State University - UNPK, 947 p.

Meyer, A. A., Heinonen, M., \& Frankel, E. N. (1998 a). Antioxidant interactions of catechin, cyanidin, caffeic acid, quercetin, and ellagic acid on human LDL oxidation. Food Chemistry, 61 (1/2), 71-75. https://doi.org/10.1016/s03088146(97)00100-3

Meyer, A. S., Donovan, J. L., Pearson, D. A., Waterhouse, A. L., \& Frankel, E. N. (1998, b). Fruit hydroycinnamic acids inhibit human lowdensity lipoprotein oxidation in vitro. Journal of Agricultural and Food Chemistry, 46, 1783-1787. https://doi.org/10.1021/jf9708960

Mezenova, O. Y., \& Kazakova, O. N. (2010). Modeling the recipe for diabetic shortbread cookies with the addition of stevia and Jerusalem artichoke. Bulletin of the International Academy of Refrigeration, 4, 21-24.

Mohan, G., Raju, J., Shiny, R., Abhilash, P. V., \& Soumya, S. (2019). Biochemical, mineral and proximate composition of Indian cassava varieties IJCS, 7(4), 1059-1065.

Monti, A., Amaducci, M. T., \& Venturi, G. (2005). Growth response, leaf gas exchange and fructans accumulation of Jerusalem artichoke (Helianthus tuberosus L.) as affected by different water regimes. European Journal of Agronomy, 23(2), 136-145. https://doi.org/10.1016/j.eja.2004.11.001

Munim, A., Rod, M. R., Tavakoli, H., \& Hosseinian, F. (2017). An analysis of the composition, health benefits, and future market potential of the jerusalem artichoke in canada. Journal of Food Research,6(5), 69 69. https://doi.org/10.5539/jfr.v6n5p69

Nakhmedov, F. G., \& khozakademie, R. (1994). The technology of cultivation, processing and consumption of chicory. Food Industry, 2

National Research Council. (1989). Diet and Health: Implications for Reducing Chronic Disease Risk.

Nguyen, V. C., Kurata, T., Kato, H., \& Fujimaki M., 1982. Antimicrobial activity of kumazasa (Sasaalbo-marginita). Agricultural and Biological Chemistry, 46 (4), 971-978. https://doi.org/10.1271/bbb1961.46.971

Nikolaevich, Z.V. (2000). food supplement from Jerusalem artichoke with macro- and microelements, which has biological activity. http://www.freepatent.ru/patents/2152736

Nikolaevna, S.T., Georgievna, E.L., \& Pavlovna, B.I. (2012). Meat Minced Products. https://yandex.ru/patents/doc/RU2502345C1 20131227

Oladele, A. K., \& Aina, J. O. (2007). Chemical composition and functiona properties of flour produced from two varieties of tigernut (Cyperus 
esculentus). African Journal of Biotechnology, 6(21). https://doi.org/10.5897/ajb2007.000-2391

Osama, A., Engy, R., \& Gehad, E. (2014). Immunomodulatory effect of artichoke (Cynara scolymus) on carbon tetrachloride induced immunosuppression in rats. Annals of Veterinary and Animal Science, 1, 66-76

Özer, C. O. (2019). Utilization of Jerusalem artichoke powder in production of low-fat and fat-free fermented sausage. Italian Journal of Food Science, 31(2) 301-310.

Ozgoren, E., Isik, F., \& Yapar, A. (2019). Effect of Jerusalem artichoke (Helianthus tuberosus L.) supplementation on chemical and nutritional properties of crackers. Journal of Food Measurement and Characterization, 13(4), 2812 2821. https://doi.org/10.1007/s11694-019-00201-9

Pandino, G., Lombardo, S., \& Mauromicale, G. (2011). Mineral profile in globe artichoke as affected by genotype, head part and environment. Journal of the Science of Food and Agriculture, 91, 302-308. https://doi.org/10.1002/jsfa.4185 Pavlova, V. (2014). Functional foods based on Jerusalem artichoke. Journal of Food and Packaging Science, Technique and Technologies, 59-63.

Polyansky, K.K., Rodionova N.S., \& Glagoleva L.E. (1999). method for the production of a dairy therapeutic and prophylactic product http://www.freepatent.ru/patents/2130731

Ponomareva, M., Krikunova, L., \& Yudina, T. (2009). Functional bread using Jerusalem artichoke oil cake. Bread products, (10), 44-45.

Pool-Zobel, B., Van Loo, J., Rowland, I., \& Roberfroid, M. (2002). Experimenta evidences on the potential of prebiotic fructans to reduce the risk of colon cancer. British Journal of Nutrition, 87, 273-281.

Puyanda, I. R., Uriyapongson, S., \& Uriyapongson, J. (2020). Influence of drying method on qualities of Jerusalem artichoke (Helianthus tuberosus L.) tuber harvested in Northeastern Thailand. Songklanakarin Journal of Science \& Technology, 42(6).

Radovanovic, A. M., Milovanovic, O. Z., Kipic, M.Z., Ninkovic, M. B., \& Cupara, S. M. (2014). Characterization of Bread Enriched with Jerusalem Artichoke Powder Content. Journal of Food and Nutrition Research, 2 (12), 895898. https://doi.org/10.12691/jfnr-2-12-6

Radovanovic, A., Stojceska, V., Plunkett, A., Jankovic, S., Milovanovic, D., \& Cupara, S. (2015). The use of dry Jerusalem artichoke as a functional nutrient in developing extruded food with low glycaemic index. Food Chemistry, 177, 81 88. https://doi.org/10.1016/j.foodchem.2014.12.096

Rigo A., Vianello, F., Clementi, G., Rossetto, M., Scarpa, M., Vrhovek, U., \& Mattivi, F. (2000). Contribution of proanthocyanidins to the peroxy radical scavenging capacity of some Italian red wines. Journal of Agricultural and Food Chemistry, 48, 1996-2002. https://doi.org/10.1021/jf991203d

Roberfroid, M. B. (2005). Introducing inulin-type fructans. British Journal of Nutrition, 93(S1)

https://doi.org/10.1079/bjn20041350

Rebora, C. (2008). Topinambur (Helianthus tuberosus L.): usos, cultivos y potencialidad en la región de cuyo. Horticultura Argentina, 27 (63), 30-37.

Shazzo R.I., Tamazova S.Yu., Fatkina E.V., Kupin G.A. (2013). Storage and processing of agricultural raw materials. No. 12. S. 12-13.Changes in the chemical composition of late-ripening Jerusalem artichoke. Interest in the period of plant growth. 12, 12-13.

Shazzo, R.A., Gish, R.I., Ekutech, E.P., \& Kornen, V.G. (2013). Kaishev: ed R.I. Shazzo; GNU Krasnodar. nauchn.-issled. in-t of storage and processing with.-kh. products. Krasnodar: Publishing House - South, 184 p.

Sonnante, G., Depaolis, A., Lattanzio, V., \& Perrino, P. (2002). Genetic variation in wild and cultivated artichoke revealed by RAPD markers. Genetic Resources and Crop Evolution, 49, 247-252. https://doi.org/10.1023/a:1015574627621

Szewczyk, A., Zagaja, M., Bryda, J., Kosikowska, U., Stępień-Pyśniak, D., Winiarczyk, S., \& Andres-Mach, M. (2019). Topinambur-new possibilities for use in a supplementation diet. Annals of Agricultural and Environmental Medicine, 26(1), 24-28.

Takuo, O., Yoshiyuki, K., Takashi, Y., Tsutomu, H., Hiromichi, O., \& Shigeru, A. (1983). Studies on the activities of tannins and related compounds from medical plants and drugs I. Inhibitory effect on lipid peroxidation in mitochondria and microsomes of liver. Chemical Pharmaceutical Bulletin, 31 (5), 1625-1631. https://doi.org/10.1248/cpb.31.1625

Tassoni, A., Bagni, N., Ferri, M., Franceschetti, M., Khomutov, A., Marques, M. P., \& Serafini-Fracassini, D. (2010). Helianthus tuberosus and polyamine research: past and recent applications of a classical growth model. Plant $\begin{array}{lll}\text { Physiology and } & \text { Biochemistry, 48(7), } & \text { 496-505 }\end{array}$ https://doi.org/10.1016/j.plaphy.2010.01.019

Tchoné, M., Barwald, G., Annemuller, G., \& Fleischer, L. (2006). Separation and identification of phenolic compounds in Jerusalem artichoke (Helianthus $\begin{array}{llll}\text { tuberosus } & \text { L.). Sciences des aliments, 26(5), } 394 .\end{array}$ https://doi.org/10.3166/sda.26.394-408

Tesaki, S., Tanabe, S., Ono, H., Fukushi, E., Kawabata J., \& Watanabe M. (1998). 4-Hydroxy-3-nitrophenylacetic and sinapinsäure as antibacterial compounds from mustard seeds. Bioscience, Biotechnology and Biochemistry, 62 (5), 998-1000. https://doi.org/10.1271/bbb.62.998

Tokarev, V.Y. (2018). Development of technology and assessment of consumer properties of semi-finished products from Jerusalem artichoke tubers.
Dissertation for the degree of candidate of technical sciences: 05.18 .15 Technology and commodity science of food products for functional and specialized purposes and public catering. - Kuban State Technological University. - Krasnodar, 180 p.

Towviriyakul, A., Jitinandana, S., Judprasong, K., \& Nitithamyong, A. (2012) Formulation of Jerysalem artichoke (Helianthus tuberosus L.) juice. In 1st Mae Fah Luang University International Conference. Institute of Nutrition. Thailand (pp. 1-8).

Van Loo, J., Cummings, J., Delzenne, N., Englyst, H., Franck, A., Hopkins, M., .. \& van den Heuvel, E. (1999). Functional food properties of non-digestible oligosaccharides: a consensus report from the ENDO project (DGXII AIRIICT94-1095). British Journal of Nutrition, 81(2), 121-132. https://doi.org/10.1017/s0007114599000252

Vinogradova, A. V., Paklina, O. V., \& Anashkina, E. N. (2010). Jerusalem artichoke is a promising raw material for biotechnology. Bulletin of the Perm National Research Polytechnic University. Chemical Technology and Biotechnology, 11, 137-142. (in Russian)

Volkova, O.P., Frampol'skaya, T.V., \& Kichatova, V.O. (1999). Milk serumbased beveragehttps://patents.google.com/patent/RU2181248C2/ru.

Volkova O.P., Frampolskaya T.V., \& Chukhlib V.N. (2001). method of making diet curd dessert. http://www.freepatent.ru/patents/2166257

Wang, Y., Zhao, Y., Xue, F., Nan, X., Wang, H., Hua, D., \& Xiong, B. (2020) Nutritional value, bioactivity, and application potential of Jerusalem artichoke (Helianthus tuberosus L.) as a neotype feed resource. Animal Nutrition, 6(4) 429-437. https://doi.org/10.1016/j.aninu.2020.09.001

Wardkaw, G. M., \& Kessel, M. (2002). Perspective in nutrition 5th Ed.

Yang, L., He, Q. S., Corscadden, K., \& Udenigwe, C. C. (2015). The prospects of Jerusalem artichoke in functional food ingredients and bioenergy production. Biotechnology Reports, 5 ,

$77-88$ https://doi.org/10.1016/j btre 2014.12.004

Yaroshevich, M.I. (2010). Jerusalem artichoke (Helianthus tuberosus L) is a promising culture of multipurpose use / M.I. Yaroshevich, N.N. Evening Proceedings of BSU, 4(2), 1-12.

Ying, D., Zhiyu, X., Yansheng, Z., Xinghua, Z. (2015). Application of jerusalem artichoke whole powder and meat product containing jerusalem artichoke whole powder

https://worldwide.espacenet.com/patent/search/family/053548728/publication/C N104783178A?q=Jerusalem\%20artichoke\%2C\%20meat

Zhang, W., Xu, P., \& Zhang, H. (2015). Pectin in cancer therapy: a review. Trends in Food Science \& Technology, 44(2), 258-271. https://doi.org/10.1016/i.tifs.2015.04.001

Zelenkov, V. N. (2001). Medical and biological properties of Jerusalem artichoke (dried) and the experience of using dietary supplements based on it in medical practice. Agrarian Russia, 6, 23-25.

Zelenkov, V.N., \& Shain , S.S. (2000). The many-sided Jerusalem artichoke in the past and present / Novosibirsk: Aris. 242p.

Zelenkov, V.N. Jerusalem artichoke: agrobiological portrait and prospects of innovative application / V. N. Zelenkov, N. G. Romanova. - Moscow: RGAUMSKHA, 2012 - 161 p. Kochnev, N.K. Jerusalem artichoke bioenergetic culture of the XXI century / N.K. Kochnev, M.V. Kalinicheva - M .: Printing house "Ares", 2002. - 76 p. (In Russian).

Zhuchkova, M.A., \& Skripnikova, S.G. (2017). Jerusalem artichoke is a plant of 21st century. Овощии России, 1, 31-33. 